\title{
Novel Quinoline Derivatives as Antitumor Agents Against HepG2 Cells: Synthesis, Characterization, In Silico, In Vitro and Docking Studies
}

\author{
Sahar S. El-Sakka ${ }^{1}$. Mohamed H. A. Soliman ${ }^{1}$ and Omaima E.A. Mohamed ${ }^{2 *}$ \\ ${ }^{1}$ Suez University, Faculty of Science, Chemistry Department, Suez, Egypt. \\ ${ }^{2}$ Chemistry Administration, Suez, Egypt.
}

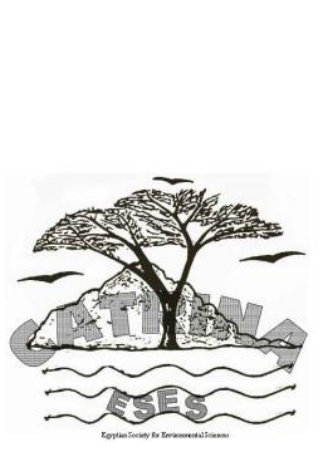

\section{INTRODUCTION}

The synthesis of quinoline and its derivatives have attracted considerable attention of chemists in the field of organic and medicinal chemistry for many years (Kouznetsov et al., 2005) . The structural core of quinoline is frequently associated with medicinal and pharmaceutical applications (Bénard et al., 2004; Borioni et al., 2007; Desrivot et al., 2007; Musiol et al., 2006) The intensive efforts to find effective therapeutic agents with antiviral and antitumor activities have directed many researchers to synthesize a series of quinoline derivatives or their analogues.

The Pfitzinger reaction is a divergent approach to the synthesis of 2-substituted quinoline-4-carboxylic acids by the reaction of isatin with ketones in the presence of a strong nucleophile (such as hydroxide). Pfitzinger's own studies of the late nineteenth century indicate this reaction is generally efficient (Shvekhgeimer, 2004). Zhu and coworkers (Zhu et al., 2010), noting the dea-rth of methods to obtain quinoline-4-carboxylic acids unsubstituted in the 2-position, utilized the Pfitzinger reaction in combination with selective decarboxylation to obtain these analogs. Elghamry and Al-Faiyz (Elghamry and Al-Faiyz, 2016) investigated the use of enaminones as the ann-ulation partner in the Pfitzinger synthesis of 3-aroy-lketone quinoline-4-carboxylic acids.

Quinoline and its analogs represent privileged moieties in the field of synthetic and medicinal chemistry because of its diverse chemical and pharmacological properties. The broad spectrum of biological and biochemical activities has been further facilitated by the synthetic versatility of quinoline, which allows the generation of a large number of structurally diverse derivatives (Solomon and Lee, 2011).

Compounds containing the quinoline moieties were found to be the oldest chemicals for the treatment of various diseases (Solomon and Lee, 2011). The extremely drug resistant tuberculosis is a worldwide public health problem in recent years. The wide spread of this disease is primarily due to the development of resistance to the existing drugs that has concerned researchers throughout the world. There is an urgent requirement of improvement in new drug molecules with newer targets and with an alternative mechanism of action (Koul et al., 2011; Mandewale et al., 2018).

According to the history of the important applications of the quinoline derivatives, this work introduces some new quinoline derivatives with new trend in the level of theoretical and experimental prospects. The new view of the synthesized compounds in the level of in vitro and in silico was attained to deep prospective view. Also, the anticancer activity of the target compounds was checked using the in vitro and in silico using the human liver carcinoma cell lines HepG2 (protein code: 5EQG).

\section{MATERIAL AND METHODS}

\section{Materials}

All chemicals used in this study were of analytical grade. The primitive chemicals (Koch-Light and SigmaAldrich) were used as received.

\section{Apparatus}

Thin layer chromatography (TLC) was carried out on silica gel type 60-F254 aluminum sheets (E. Merck, layer thickness $=0.2 \mathrm{~mm}$ ) using the following solvent systems, S1: petroleum ether $\left(40-60{ }^{\circ} \mathrm{C}\right) / \mathrm{ethyl}$ acetate (5:1); S2: petroleum ether $\left(40-60^{\circ} \mathrm{C}\right) /$ ethyl acetate $(2: 1)$; S3: petroleum ether $\left(40-60{ }^{\circ} \mathrm{C}\right) /$ ethyl acetate $(1: 1)$. The obtained spots were detected by UV lamp. Melting points were determined on $300{ }^{\circ} \mathrm{C}$ melting point apparatus and the values are used without extra correction. The infrared spectra were obtained in the 4000-400 $\mathrm{cm}^{-1}$ region by using Bruker Alpha instrument with $\mathrm{KBr}$ disc technique. ${ }^{1} \mathrm{H}$ and ${ }^{13} \mathrm{CNMR}$ spectra were recorded on Bruker spectrometer operating at 300 and $75.0 \mathrm{MHz}$ uses $\mathrm{CDCl}_{3}$ as solvent and TMS as internal standard. Elemental analysis was carried out by elementarvario instrument.

\footnotetext{
* Corresponding author, E-mail: oeam70@hotmail.com
} 


\section{In Vitro anti-tumor activity}

The effect of the target compounds on the growth of HepG2 cell lines was evaluated according to the procedure adopted using Skehan method (Skehan et al., 1990). Cisplatin was used as a standard to assess the cytotoxicity of compounds. The capabilities of the synthesized compounds to arrest the proliferation of tumor cells were evaluated after $48 \mathrm{~h}$ of incubation. The results were analyzed by means of cell viability curves and expressed as $\mathrm{IC}_{50}$ values. Cells were plated in 96-well plate (104 cells/well) for $24 \mathrm{~h}$ by using RPMI-1640 media before treatment with the compounds to allow attachment of cell to the wall of the plate. Different concentrations of the compound under investigation $(1,5,10$, 25 and $50 \mathrm{mM}$ ) were added to the cell monolayer which are then incubated with the compounds for $48 \mathrm{~h}$ at $37^{\circ} \mathrm{C}$ and in atmosphere of $5 \% \mathrm{CO}_{2}$.

\section{Synthesis of the Target Quinoline derivatives}

(A) Synthesis of 2-oxo-1, 2-dihydroquinoline-4-carboxylicacid (1)

To a solution of isatin (a) $(1 \mathrm{~g}, 6.8 \mathrm{mmol})$ and malonic acid (b) $(0.7 \mathrm{~g}, 6.7 \mathrm{mmol})$ in glacial acetic acid $(6 \mathrm{ml})$, fused sodium acetate $(0.1 \mathrm{~g}, 1.2 \mathrm{mmol})$ was added. The reaction mixture was refluxed for $3 \mathrm{~h}$. After cooling to room temperature, the obtained precipitate was filtered off, washed several times with methanol and dried at room temperature to give: 2-oxo-1,2-dihydroquinoline4-carboxylicacid (1) (Scheme 1), brown powder (1.06 g, $83 \%$ ), $\mathrm{mp}>300{ }^{\circ} \mathrm{C}, \mathrm{Rf}=0.52$ (S4). Anal. Calcd. for $\mathrm{C}_{10} \mathrm{H}_{7} \mathrm{NO}_{3}$ (189.17): C, 63.49; H, 3.73; N, 7.40. Found: C, 63.22; H, 3.89; N, 7.73.

(B) Synthesis of methyl 2-oxo-1, 2-dihydroquinoline-4-carboxylate (2)

To a solution of 2-oxo-1, 2-dihydroquinoline-4-carboxylicacid acid (1) $(0.97 \mathrm{~g}, 5.1 \mathrm{mmol})$ in absolute methanol $(20 \mathrm{ml})$, concentrated Sulphuric acid $(2 \mathrm{ml})$ was added dropwise. The reaction mixture was refluxed in a water bath for $13 \mathrm{~h}$. After cooling to room temperature, a solution of sodium carbonate was added. The formed precipitate was filtered off, washed with methanol several times, and then left at room temperature to dry, yielding:methyl-2-oxo-1,2-dihydroquinoline-4-carboxylate (2) (Scheme1): fainty pink powder $(0.8 \mathrm{~g}, 76.9 \%)$, mp $238{ }^{\circ} \mathrm{C}, \mathrm{Rf}=0.50(\mathrm{~S} 2) .{ }^{1} \mathrm{HNMR}(300.0 \mathrm{MHz}$, $\left.\mathrm{CDCl}_{3}\right): \delta=12.10(1 \mathrm{H}, \mathrm{br}, \mathrm{NH}), 8.02(1 \mathrm{H}, \mathrm{d}, \mathrm{J}=9.0 \mathrm{~Hz}$, ArH), $7.56(1 \mathrm{H}, \mathrm{t}, \mathrm{J}=9.0, \mathrm{~Hz}, \mathrm{ArH}), 7.38(1 \mathrm{H}, \mathrm{d}, \mathrm{J}=$ $9.0 \mathrm{~Hz}, \mathrm{ArH}), 7.23(1 \mathrm{H}, \mathrm{t}, \mathrm{J}=9.0 \mathrm{~Hz}, \mathrm{ArH}), 6.90(1 \mathrm{H}, \mathrm{s}$, $\mathrm{ArH}), 3.92\left(3 \mathrm{H}, \mathrm{s}, \mathrm{CH}_{3}\right) .{ }^{13} \mathrm{CNMR}\left(75.0 \mathrm{MHz}, \mathrm{CDCl}_{3}\right): \delta$ $=166.0(\mathrm{CO}), 161.2(\mathrm{ArCO}), 140.3,139.8,131.4,126$ 126.3, 124.5, 122.7, 116.3, 115.3 (Ar-C), $53.3\left(\mathrm{OCH}_{3}\right)$. Anal. Calcd. for $\mathrm{C}_{11} \mathrm{H}_{9} \mathrm{NO}_{3}$ (203.20): C, 65.02; H, 4.46; N, 6.89; Found: C, 64.93; H, 4.77; N, 7.08.

(C) Synthesis of methyl 2-(allyloxy) quinoline-4carboxylate (3), methyl 1-allyl-2-oxo-1, 2-dihydroquinoline-4-carboxylate (4)

To a solution of methyl 2-oxo-1, 2-dihydroquinoline4-carboxylate (2) (5 g, $24.61 \mathrm{mmol}$ ) in dry dimethyllformamide $(30 \mathrm{ml})$, sodium hydride $60 \%$ (1.5 g, 62.50 mmol) was added dropwise. The reaction mixture was refluxed for $1 \mathrm{~h}$ then cooled to room temperature. An allyl bromide ( $5 \mathrm{ml}, 41.32 \mathrm{mmol}$ ) was added and the mixture was stirred at room temperature overnight. The reaction mixture was poured on water $(100 \mathrm{ml})$ in a beaker. The resultant mixture was extracted with chloro-form $(100 \mathrm{ml})$ and washed with water, dried over anhy-drous $\mathrm{Na}_{2} \mathrm{SO}_{4}$, filtered and the solvent was evaporated at room temperature. The residue was treated by column chromatography using petroleum ether $\left(40-60{ }^{\circ} \mathrm{C}\right) /$ ethyl acetate $(20: 1,15: 1,10: 1)$ as eluent. The solvent was evaporated at room temperature. The products were chromatographed by petroleum ether $\left(40-60{ }^{\circ} \mathrm{C}\right) / \mathrm{ethyl}$ acetate (5:1) to give a mixture from methyl 2-(allyloxy) quinoline-4-carboxy-late (3), and methyl 1-allyl-2-oxo1,2-dihydro-quino-line-4-carboxylate (4) (S-cheme 1).

(C1) Synthesis of methyl 2-(allyloxy) quinoline-4-carboxylate (3)

Yellow crystal $(3.0 \mathrm{~g}, 50 \%), \mathrm{Rf},=0.70(\mathrm{~S} 2) .{ }^{1} \mathrm{HNMR}$ $\left(300.0 \mathrm{MHz}, \mathrm{CDCl}_{3}\right) \delta=8.62(1 \mathrm{H}, \mathrm{d}, \mathrm{J}=9.0 \mathrm{~Hz}, \mathrm{ArH})$, $7.90(1 \mathrm{H}, \mathrm{d}, \mathrm{J}=9.0 \mathrm{~Hz}, \operatorname{ArH}), 7.68(1 \mathrm{H}, \mathrm{t}, \mathrm{J}=9 \mathrm{~Hz}, \operatorname{ArH})$, 7.52-7.46 ( $1 \mathrm{H}, \mathrm{m}, \mathrm{Ar} \mathrm{H}), 7.28$ ( $1 \mathrm{H}, \mathrm{s}, \mathrm{ArH}), 6.25-$ $6.11(1 \mathrm{H}, \mathrm{m}, \mathrm{CH}=), 5.49,5.32(2 \mathrm{H}, 2 \mathrm{~d}, \mathrm{~J}=18.0,12.0 \mathrm{~Hz}$, $\left.=\mathrm{CH}_{2}\right), 5.06\left(2 \mathrm{H}, \mathrm{d}, \mathrm{J}=6.0 \mathrm{~Hz}, \mathrm{OCH}_{2}\right), 4.03(3 \mathrm{H}, \mathrm{s}$, $\left.\mathrm{OCH}_{3}\right) .{ }^{13} \mathrm{CNMR}\left(75.0 \mathrm{MHz}, \mathrm{CDCl}_{3}\right) \delta=166.2(\mathrm{CO}$ ester), 160.9 (Ar-CO ) 147.5, $137.9(\mathrm{Ar}-\mathrm{C}), 133.2(=\mathrm{CH})$ ,129.8, 127.7, 125.5, 125.2, 122.0 ( Ar- C), $117.8\left(=\mathrm{CH}_{2}\right)$, 115.4 (Ar-C), $66.8\left(\mathrm{OCH}_{2}\right), 52.6\left(\mathrm{OCH}_{3}\right)$. Anal. Calcd. for $\mathrm{Cl}_{4} \mathrm{H}_{3} \mathrm{NO}_{3}$ (243.26): C, 69.12; $\mathrm{H}, 5.39 ; \mathrm{N}, 5.76$; Found: C, 69.44; H, 5.58; N, 5.80.

(C2) methyl 1-allyl-2-oxo-1, 2-dihydroquinoline-4-carboxylate (4)

Yellow oil, $\mathrm{Rf}=0.60(\mathrm{~S} 2) .{ }^{1} \mathrm{HNMR}(300.0 \mathrm{MHz}$, $\left.\mathrm{CDCl}_{3}\right)=8.21(1 \mathrm{H}, \mathrm{d}, \mathrm{J}=9.0 \mathrm{~Hz}, \mathrm{ArH}), 7.45(1 \mathrm{H}, \mathrm{t}, \mathrm{J}=$ $9.0 \mathrm{~Hz}, \operatorname{ArH}), 7.26(1 \mathrm{H}, \mathrm{d}, \mathrm{J}=9.0 \mathrm{~Hz}, \mathrm{ArH}), 7.15(1 \mathrm{H}, \mathrm{t}, \mathrm{J}$ $=9.0 \mathrm{~Hz}, \mathrm{ArH}), 7.10(1 \mathrm{H}, \mathrm{s}, \mathrm{ArH}), 5.92-5.79(1 \mathrm{H}, \mathrm{m}$, $\mathrm{CH}=), 5.13,5.01(2 \mathrm{H}, 2 \mathrm{~d}, \mathrm{~J}=12.0 \mathrm{~Hz}, \mathrm{~J}=15.0 \mathrm{~Hz}$, $\left.=\mathrm{CH}_{2}\right), 4.86\left(2 \mathrm{H}, \mathrm{d}, \mathrm{J}=6.0 \mathrm{~Hz}, \mathrm{CH}_{2}-\mathrm{N}\right), 3.90(3 \mathrm{H}, \mathrm{s}$, $\left.\mathrm{OCH}_{3}\right) .{ }^{13} \mathrm{CNMR}\left(75.0 \mathrm{MHz}, \mathrm{CDCl}_{3}\right) \delta=165.6(\mathrm{CO}$ ester), 160.7 (Ar-CO), 139.5, 138.7 (Ar-C), $131.3(\mathrm{CH}=)$, 131.0, 127.0, 124.0, 122.5, 117.4 (Ar-C), $117.2\left(=\mathrm{CH}_{2}\right)$, 115.1 (Ar-C), $52.7\left(\mathrm{OCH}_{3}\right), 44.7\left(\mathrm{NCH}_{2}\right)$. Anal. Calcd. for $\mathrm{C}_{1} \mathrm{H}_{3} \mathrm{NO}_{3}$ (243.26): C, 69.12; H, 5.39; N, 5.76. Found: C, 68.87; H, 5.64; N, 5.62.

(D) Synthesis of 2-(allyloxy) quinoline-4-carohydrazide (5)

To a solution of ester (3) (1.6 g, $6.5 \mathrm{mmol})$ in methanol $(30 \mathrm{ml})$, hydrazine hydrate $(2 \mathrm{ml}, 41.11 \mathrm{mmol})$ was added. The reaction mixture was refluxed for $6 \mathrm{~h}$. After cooling to room temperature, the precipitated hydrazide was filtered off, washed with water and methanol followed by crystallization from aqueous methanol to yield: 2-(allyloxy)quinoline-4carbohydrazide (5) (Scheme 2), white powder (1.2 g, $75.0 \%$ ), m.p $168{ }^{\circ} \mathrm{C}, \mathrm{Rf}=0.67\left(\mathrm{~S}_{2}\right) .{ }^{1} \mathrm{HNMR}(300.0$ $\left.\mathrm{MHz}, \mathrm{CDCl}_{3}\right) \delta=9.88(1 \mathrm{H}, \quad$ br, $\mathrm{NH}), 8.05(1 \mathrm{H}, \mathrm{d}$, $\mathrm{J}=9.0 \mathrm{~Hz}, \operatorname{ArH}), 7.80(1 \mathrm{H}, \mathrm{d}, \mathrm{J}=9.0 \mathrm{~Hz}, \operatorname{ArH}), 7.72-7.67$ $(1 \mathrm{H}, \mathrm{m}, \mathrm{ArH}), 7.48-7.43(1 \mathrm{H}, \mathrm{m}, \mathrm{ArH}), 6.97(1 \mathrm{H}, \mathrm{s}$, $\left.\mathrm{ArH}), 6.25-6.12(1 \mathrm{H}, \mathrm{m}, \mathrm{CH}=), 5.52,5.34 \mathrm{br}, \mathrm{NH}_{2}\right)$. ${ }^{13} \mathrm{CNMR}\left(75.0 \mathrm{MHz}, \mathrm{CDCl}_{3}\right) \delta=165.8(\mathrm{CO}), 161.5$ 

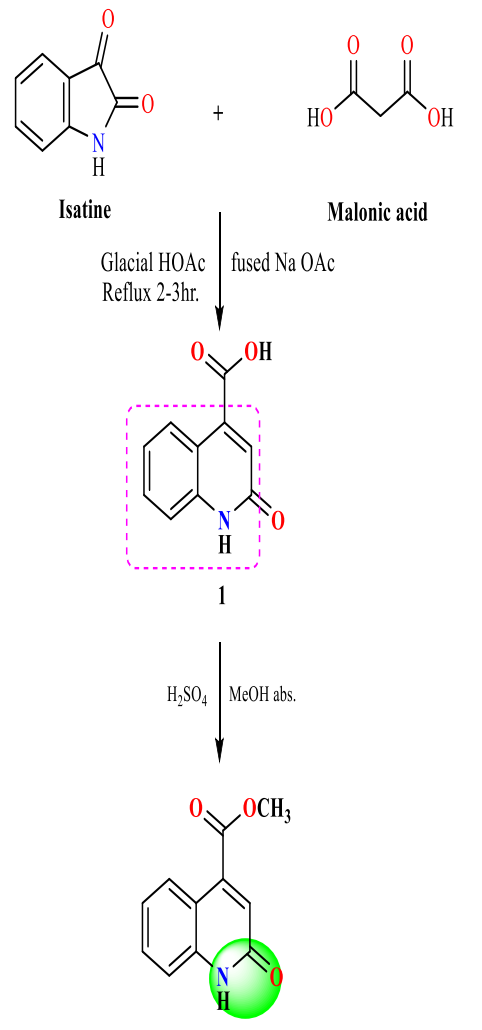

2
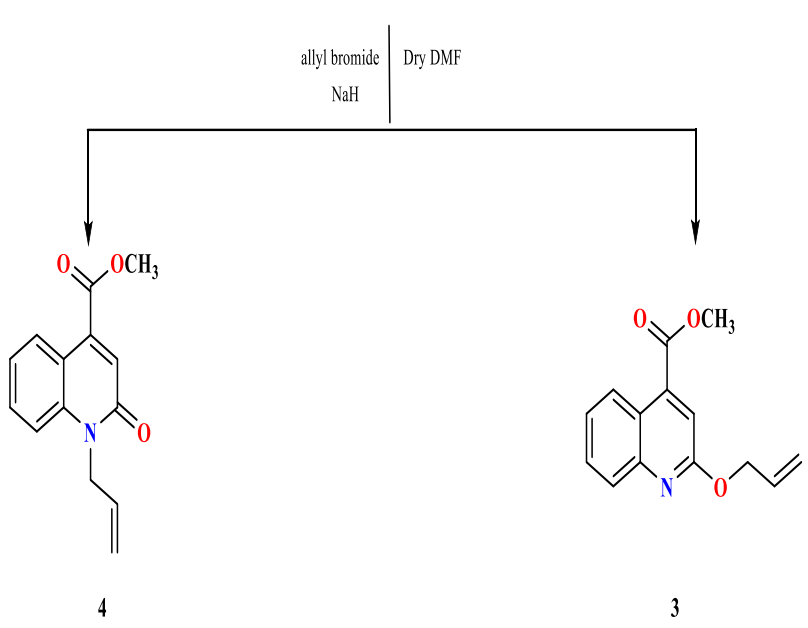

Scheme (1): Synthesis of quinoline-allyl derivatives.

(Ar-CO), 146.8, 144.6 (Ar-C), $133.3(\mathrm{CH}=), 130.5$, 127.5, 125.9, 124.9, 122.1 (Ar-C), 117.8 (=CH2), 111.7. $(\mathrm{Ar}-\mathrm{C}), 67.7\left(\mathrm{OCH}_{2}\right)$. Anal. Calcd. For $\mathrm{Cl}_{3} \mathrm{H}_{3} \mathrm{~N}_{3} \mathrm{O}_{2}$ (243.27): C, 64.19; H, 5.39; N, 17.27 Found: C, 64.02; $\mathrm{H}, 5.69 ; \mathrm{N}, 17$.

(E) General procedure for the synthesis of (E)-2(allyloxy)- $N$-(benzylidene) quinoline-4-carbohydrazide derivatives (6a-c)

A mixture of hydrazide (5) (0.34 g, $1.4 \mathrm{mmol})$, aromatic aldehyde $(1.4 \mathrm{mmol})$ and drops of acetic acid were refluxed in ethanol $(30 \mathrm{ml})$ for $4-6 \mathrm{~h}$. After cooling to room temperature, the resulting solid was filtered off, washed with ethanol and crystallized from aqueous ethanol to afford the corresponding hydrazone derivatives (6a-c) (Scheme 2).
(F) Synthesis of 2-(allyloxy)-quinoline-4-carboxamide (7a-e)

Azide coupling method: To a cold solution $\left(-5^{\circ} \mathrm{C}\right)$ of hydrazide (5) $(0.48 \mathrm{~g}, 1.97 \mathrm{mmol})$ in acetic acid $(10 \mathrm{ml})$, conc. hydrochloric acid $(10 \mathrm{ml})$ and water $(20 \mathrm{ml})$ was added a solution of sodium nitrite $(2 \mathrm{~g}, 29 \mathrm{mmol})$ in cold water $(20 \mathrm{ml})$. After stirring at the same temperature for 15 minutes, the fainty yellow syrup was formed. The azide was extracted with cold ethylacetate, washed with cold $5 \% \mathrm{Na}_{2} \mathrm{CO}_{3}$, and then dried over anhydrous sodium sulphate. The obtained azide was used directly without further purification in the next step (5a).The previously prepared cold dried solution of azide was added to the target amines (a-e) $(9.3 \mathrm{mmol})$ in ethylacetate $(20 \mathrm{ml})$ for each one. Afterwards the reaction mixture was kept $24 \mathrm{~h}$ in refrigerator and then at room temperature for another $24 \mathrm{~h}$. Then treated by washing with $5 \% \mathrm{HCl}, 5 \% \mathrm{Na}_{2} \mathrm{CO}_{3}$ and water. Dried over anhydrous $\mathrm{Na} 2 \mathrm{SO} 4$. The solvent was evaporated, and the residue was precipitated in petroleum ether (40\%-60\%). Afterwards crystallized from PE to give 2(allyloxy) quinoline-4-carboxamide (7a-e) (Scheme2).

(G) Synthesis of methyl (2-(allyloxy) quinoline-4-carbonyl)glycinate ( $8 a-f)$

To a cold solution $\left(-5{ }^{\circ} \mathrm{C}\right)$ of hydrazide (5) (0.75 g, $3.0 \mathrm{mmol})$ in $\mathrm{HOAc}(10 \mathrm{ml})$, conc. $\mathrm{HCl}(10 \mathrm{ml})$, and water $(50 \mathrm{ml})$ was added a solution of $\mathrm{NaNO}_{2}(2 \mathrm{~g}, 29$ $\mathrm{mmol})$ in cold water $(50 \mathrm{ml})$. After stirring at $-5{ }^{\circ} \mathrm{C}$ for 15 min., the faint yellow syrup was formed. The azide was extracted with cold ethylacetate, washed with cold $\mathrm{Na}_{2} \mathrm{CO}_{3}(5 \%)$ then dried over anhydrous sodium sulphate, the azide was then used directly without further purification in the next step (5a).Amino acid methyl ester hydrochloride (AAOMe, $\mathrm{HCl}, 5.5 \mathrm{mmol}$ ), was stirred in ethylacetate $(30 \mathrm{ml})$ with triethyl amine $(1 \mathrm{ml})$ at $0{ }^{\circ} \mathrm{C}$ for 20 minutes. The formed triethyl amine hydrochloride was filtered off and the filtrate was added to the previously prepared cold dried solution of azide (5a).

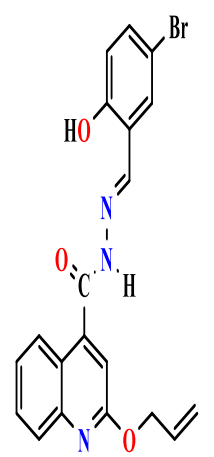

$6 a$

$-28.779$

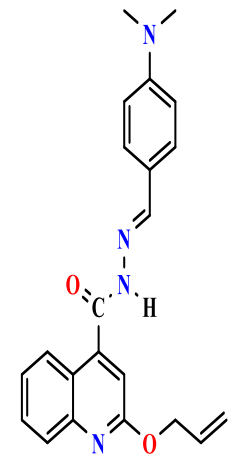

$6 \mathrm{~b}$

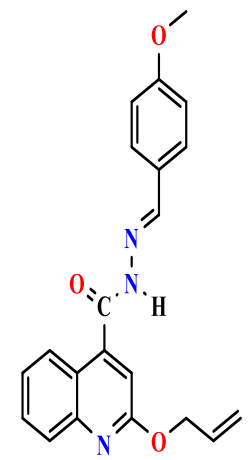

$6 \mathrm{c}$
Afterwards the reaction mixture was kept $24 \mathrm{~h}$ in refrigerator and then at room temperature for another $24 \mathrm{~h}$. The reaction mixture was washed with $5 \% \mathrm{HCl}$, $5 \% \mathrm{Na}_{2} \mathrm{CO}_{3}$ and water, then dried over anhydrous $\mathrm{Na}_{2} \mathrm{SO}_{4}$ The solvent was evaporated, and the residue was precipitated in petroleum ether (40\%-60\%) (Scheme 2). 


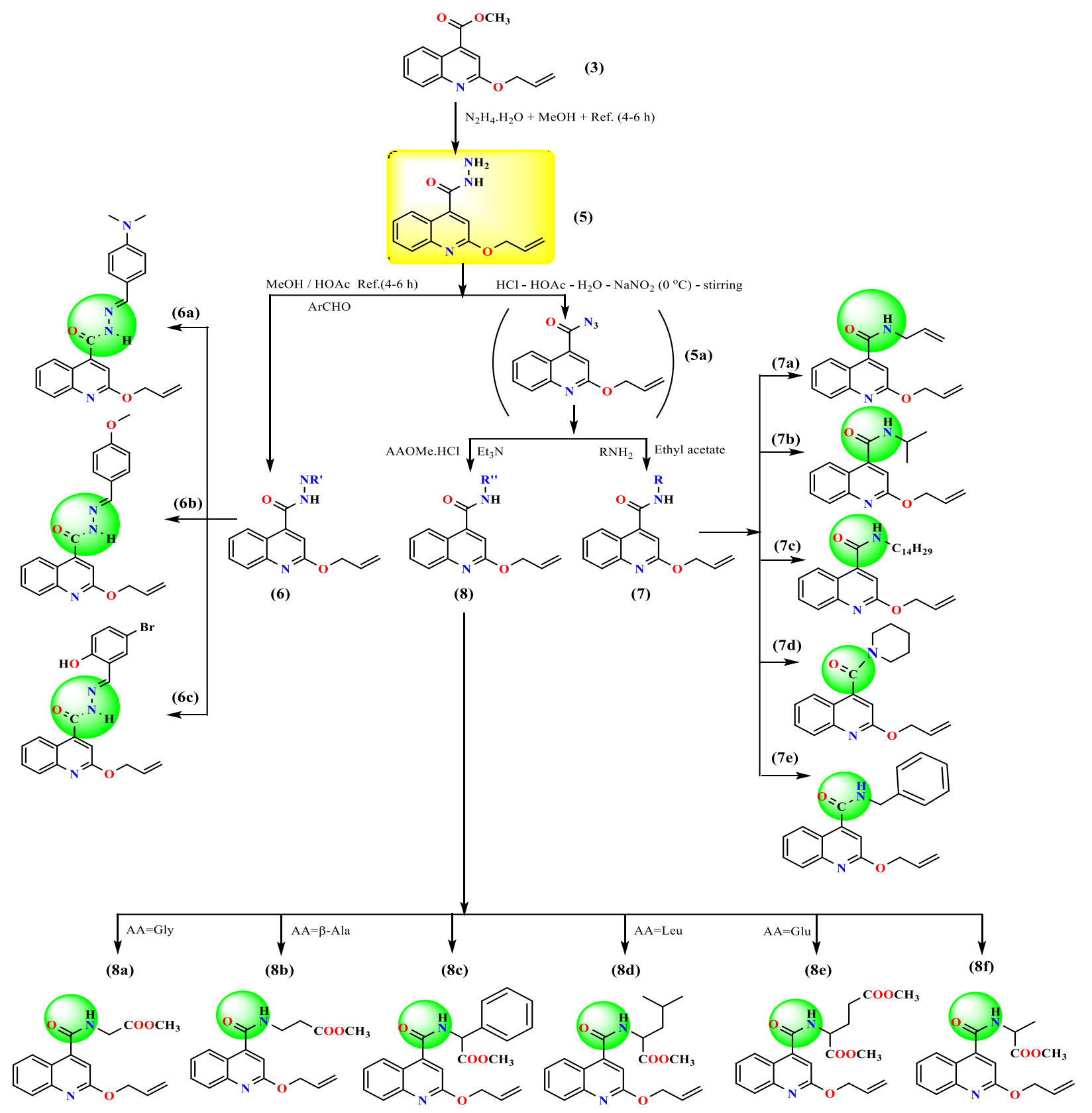

Scheme (2): Synthesis of 2- (allyloxy) quinoline-4-carbohydrazide derivatives.

\section{RESULTS AND DISCUSSION}

\section{Chemistry}

The obtained quinoline derivatives were in pure form and gave the characteristic signals in the ${ }^{1} \mathrm{HNMR}$ and ${ }^{13}$ CNMR analysis.

\section{Molecular Modeling and DFT}

The most benefit properties which play very important role in drug synthesis were referred to the surface properties of the compounds. The interaction of the drug with the living cells referred to the presence of active lone pair and the lipophilic character. Table 1 showed the active lone pair and lipophilic maps of the most abundant conformations of the compound 5 (as one demonstrative examples) using molecular operating environment (MOE) 2008.10 molecular modelling (Chemical Group Inc., 2008). The active lone pair map was denoted by three colors: violet $=\mathrm{H}$-bonding, green $=$ Hydrophobic and blue $=$ Mild polar. The H-bonding ability was concentrated in one site. The hydrophobic properties go well with the H-bonding ability.

The lipophilic map was represented using different colors, where violet $=$ Hydrophilic, white $=$ Neutral and green $=$ Lipophilic. Compound 5 gave wide green area, which indicates the large lipophilic behavior of this compound. The obtained data gave some hints about the ability of the compound 5 to be act as active compounds towards the living cells (drug) (Hisaindee et al., 2015; Musiol et al., 2006; Shahzad et al., 2015; Wang 2012). 
Table (1): The surface properties of the synthesized compound 5.

\begin{tabular}{|c|c|c|}
\hline Compound & Active lone pair map & Lipophilic and hydrophilic map \\
\hline \multicolumn{3}{|l|}{5} \\
\hline & Violet $=\mathrm{H}$-bonding & Violet $=$ Hydrophilic \\
\hline & Green $=$ Hydrophobic & White $=$ Neutral \\
\hline & Blue $=$ Mild polar & Green $=$ Lipophilic \\
\hline
\end{tabular}

\section{In Silico Docking studies}

All molecular modeling studies were performed on a Hewlett-Packard Pentium Dual-Core T4300 2.10 GHz running Windows 7 Ultimate using molecular operating environment (MOE) 2008.10 molecular modeling software (Chemical Group Inc., 2008). HepG2 was downloaded in PDB format from the Protein Data Bank (PDB) web site and used in the docking studies "(PDB; protein data bank, http://www.rcsb.org/pdb.," 2011). The docking studies were performed after deleting the co-crystallized inhibitors from the active site. Target compounds were then docked within the active site of the crystallized structures using the MOE dock tool in MOE, performed with the default values. The active site was defined by all the amino acid residues involved in the interaction with the co-crystallized inhibitors.

The docking work of the synthesized compounds with HepG2 (code: 5EQG protein) as human liver carcinoma was listed in Table 2 and shown in Figure 1. The obtained data could be discussed generally as the following:

1.Generally, the substituted hydrazide compounds gave binding energy larger than the free hydrazide compounds.

2.The increasing of the aliphatic side chain strongly enhanced the binding affinity.

3.The allay derivatives gave largest binding energy when comparing with compounds free from the allay chain.

4.The variation of $\mathrm{R}^{\prime}$ on compound 6 , gave nearly comparable binding affinity.

5.The binding affinity order for the synthesized compounds could be generally arranged as the following: O-allyl > N-allyl > un-allyl compound.

\section{In vitro Anti-Tumor Activity}

The $\mathrm{IC}_{50}$ of the target compounds (Table 3) are almost close with the reference drug Doxorubicin (DOX). Generally, the obtained data revile the very promising compounds as anticancer agents and it suitable to applied deep studies in vivo level.

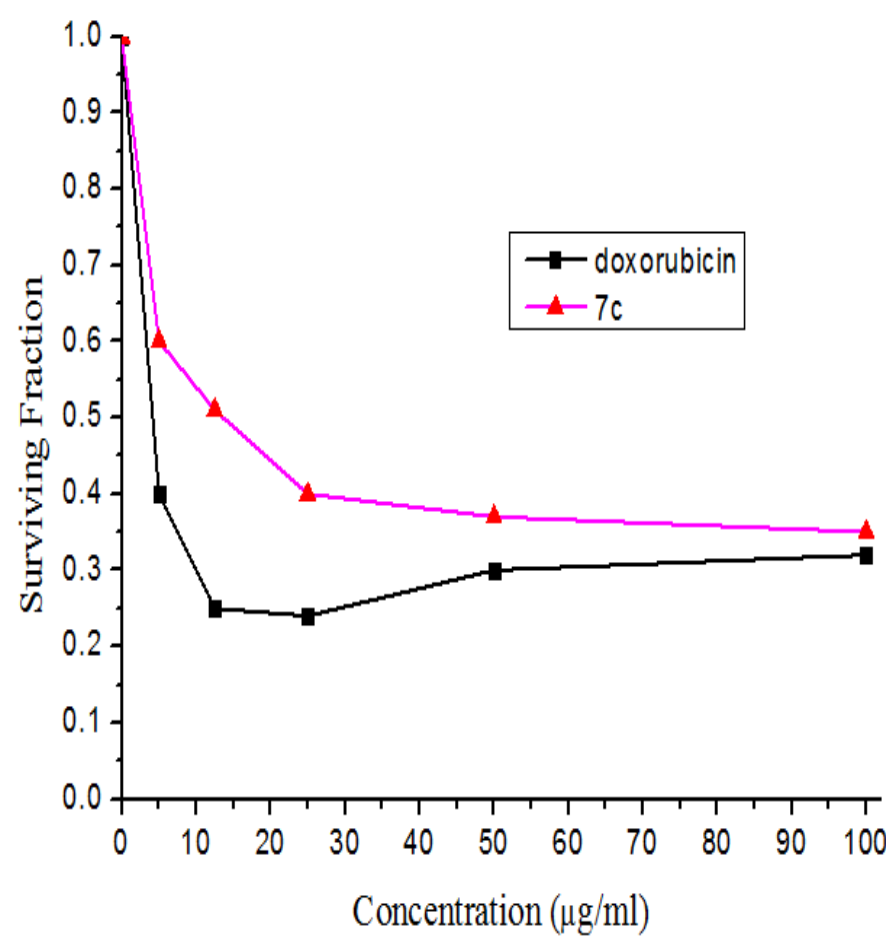

Figure (1): The variation of the tumor cell viability of Human liver carcinoma cell line (HepG2) with the target compound at different concentrations. 
Table (2): The binding energy of some target compounds with HepG2 (5EQG protein).

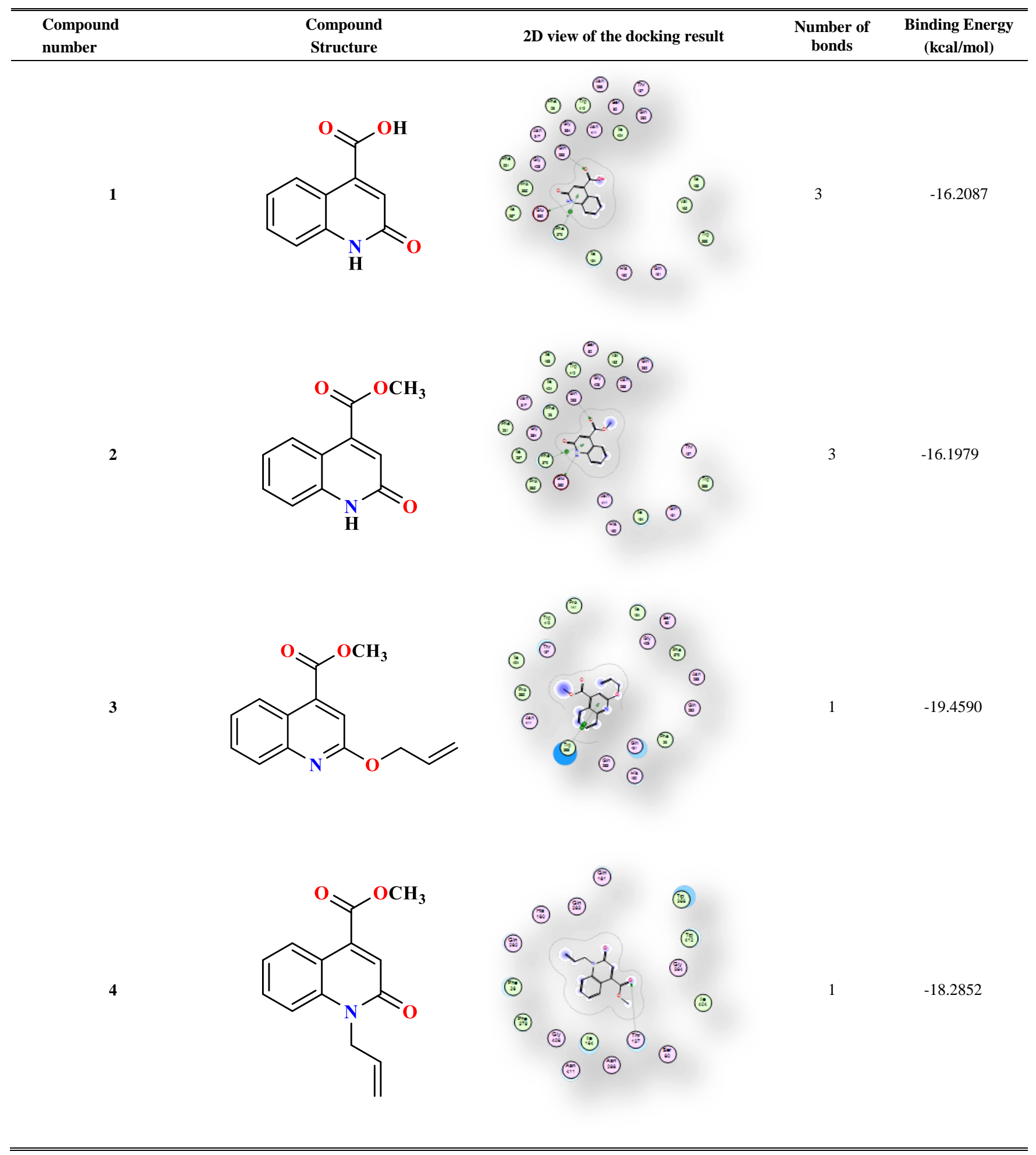


Table (3): In vitro cytotoxic activity of the target compounds with HepG2 (5EQG protein).

\begin{tabular}{|c|c|c|c|}
\hline Compound & $\begin{array}{c}\text { Concentration } \\
(\mathrm{ug} / \mathrm{ml})\end{array}$ & Mean \pm SD & $\begin{array}{c}\text { IC50 } \\
(\mathrm{ug} / \mathrm{ml})\end{array}$ \\
\hline \multirow{6}{*}{$7 c$} & 0 & $1.00 \pm 0.033$ & \multirow{6}{*}{13.456} \\
\hline & 5 & $0.6 \pm 0.056$ & \\
\hline & 12.5 & $0.51 \pm 0.077$ & \\
\hline & 25 & $0.4 \pm 0.043$ & \\
\hline & 50 & $0.37 \pm 0.055$ & \\
\hline & 100 & $0.35 \pm 0.062$ & \\
\hline \multirow{6}{*}{ Doxorubicin } & 0 & $1.00 \pm 0.033$ & \multirow{6}{*}{4.059} \\
\hline & 5 & $0.4 \pm 0.043$ & \\
\hline & 12.5 & $0.25 \pm 0.023$ & \\
\hline & 25 & $0.24 \pm 0.044$ & \\
\hline & 50 & $0.3 \pm 0.056$ & \\
\hline & 100 & $0.32 \pm 0.044$ & \\
\hline
\end{tabular}

\section{REFERENCES}

BÉNARD, C., F. ZOUHIRI, M. NORMAND-BAYLE, M. DANET, D. DESMAËLE, H. LEH, J.-F.F. MOUSCADET, G. MBEMBA, C.M. THOMAS, S. BONNENFANT, M. LE BRET, AND J. D'ANGELO. 2004. Linker-modified quinoline derivatives targeting HIV-1 integrase: Synthesis and biological activity. Bioorganic Med. Chem. Lett. 14: 2473-2476.

BORIONI, A., C. MUSTAZZA, I. SESTILI, M. SBRACCIA, L. TURCHETTO, AND M.R. DEL GIUDICE. 2007. Synthesis of new 4-heteroaryl-2phenylquinolines and their pharmacological activity as NK-2/NK-3 receptor ligands. Arch. Pharm. (Weinheim). 340: 17-25.

Chemical Group Inc. 2008. Molecular Operating Environment (MOE), Montreal, Quebec, Canada.

DESRIVOT, J., C. HERRENKNECHT, G. PONCHEL, N. GARBI, E. PRINA, A. FOURNET, C. BORIES, B. FIGADÈRE, R. HOCQUEMILLER, AND P.M. LOISEAU. 2007. Antileishmanial 2-substituted B. FIGADÈRE, R. HOCQUEMILLER, AND P.M. LOISEAU. 2007. Antileishmanial 2-substituted quinolines: In Vitro behaviour towards biological components. Biomed. Pharmacother. 61: 441-450.

ELGHAMRY, I., AND Y.A. AL-FAIYZ. 2016. Simple one-pot synthesis of quinoline-4-carboxylic acids by the Pfitzinger reaction of isatin with enaminones in water. Tetrahedron Lett. 57: 110-112.

HISAINDEE, S., L. AL-KAABI, , S.A. JEB, Y. TORKY, R. IRATNI, N. SALEH, AND S.F. ABUQAMAR. 2015. Antipathogenic effects of structurally-related Schiff base derivatives: Structure-Activity relationship. Arab. J. Chem. 8: 828-836.

KOUL, A., E. ARNOULT, N. LOUNIS, J. GUILLEMONT, AND K. ANDRIES. 2011. The challenge of new drug discovery for tuberculosis. Nature. doi:10.1038/nature09657.

KOUZNETSOV, V. V, L.Y. VARGAS MÉNDEZ, AND C.M. MELÉNDEZ GÓMEZ. 2005. Recent Progress in the Synthesis of Quinolines. Curr. Org. Chem. 9: 141-161.

MANDEWALE, M.C., B. THORAT, Y. NIVID, R. JADHAV, A. NAGARSEKAR, AND R. YAMGAR. 2018. Synthesis, structural studies and antituberculosis evaluation of new hydrazone derivatives of quinoline and their $\mathrm{Zn}$ (II) complexes. J. Saudi Chem. Soc. 22: 136-145.

MUSIOL, R., J. JAMPILEK, V. BUCHTA, L. SILVA, H. NIEDBALA, B. PODESZWA, A. PALKA, K. MAJERZ-MANIECKA, B. OLEKSYN, AND J. POLANSKI. 2006. Antifungal properties of new series of quinoline derivatives. Bioorganic Med. Chem. 14: 3592-3598.

PDB; protein data bank,http://www.rcsb.org/pdb. [WWW Document], 2011.

SHAHZAD, S., M.A. QADIR, R. RASHEED, AND M. AHMED. 2015. Synthesis of 99mTc-gemifloxacin freeze dried kits and their biodistribution in Salmonella typhi, Pseudomonas aeruginosa and Klebsiella pneumoniae. Arab. J. Chem.doi:10.1016/j.arabjc.2015.10.002.

SHVEKHGEIMER, M. 2004. The Pfitzinger reaction. (review). Chem. Heterocycl. Compd. 40: 257-294.

SKEHAN, P., R. STORENG, D. SCUDIERO, A. MONKS, J. MCMAHON, D. VISTICA, J.T. WARREN, H. BOKESCH, S. KENNEY, AND M.R. BOYD. 1990. New colorimetric cytotoxicity assay for anticancer-drug screening. J. Natl. Cancer Inst. 82: 1107-1112.

SOLOMON, V.R.R., AND H. LEE. 2011. Quinoline as a privileged scaffold in cancer drug discovery. Curr. Med. Chem. 18: 1-21.

WANG, S., X.D. JIA, M.L. LIU, Y. LU, AND H.Y. GU GUO. 2012. Synthesis, antimycobacterial and antibacterial activity of ciprofloxacin derivatives containing a N-substituted benzyl moiety. Bioorganic Med. Chem. Lett. 22: 5979-5983.

ZHU, H., R.F. YANG, L.H. YUN, AND J. LI. 2010. Facile and efficient synthesis of quinoline-4carboxylic acids under microwave irradiation. Chinese Chem. Lett. 21: 35-38. 


\section{مشتقات الكينولين الجديدة كعوامل مضادة للسرطان للخلايا HepG2 : تحضير و توصيف و الطرق الحسابية والطرق المعملية ودراسة عملية الإذخال}

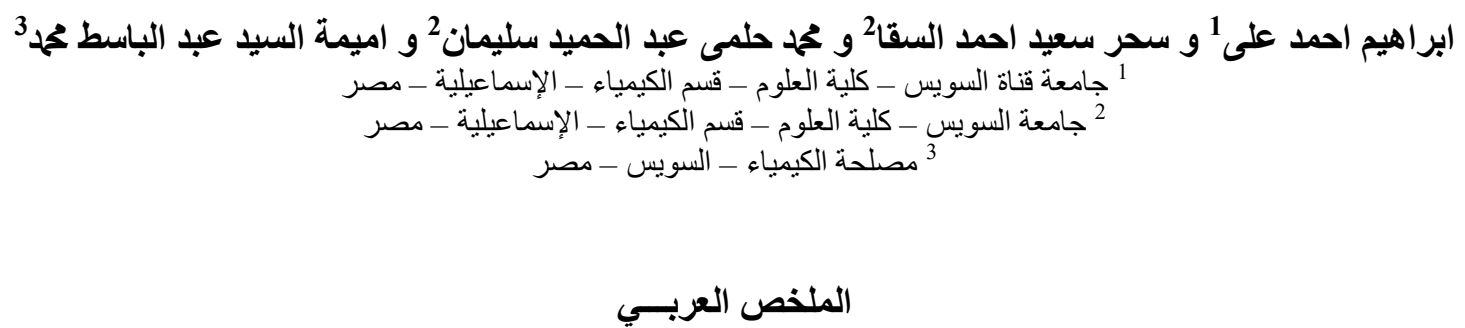

مشتقات الكينولين الجديدة والتى تحتوى على الأحماض الأمينية ومجموعة الأليل قد تم تحضير ها وتوصيفها باستخدام التحاليل العنصرية و الرنين النووى المغناطيسى. التر اكيب الفر اغية المستقرة قد تم حسابها باستخدام بعض بر امج الكمبيوتر الحديثة. النمذجة الجزيئية قد تم حسابها والتعبير

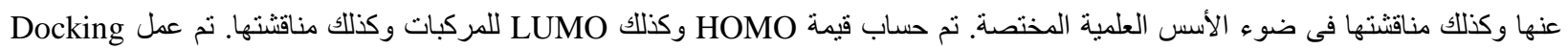
للمركبات المحضرة مع بروتين خلايا الكبد السرطانية وتم مناقشتها فى ضوء المستوى الحسابى. 